\title{
Characterization in Clonal Selections of Citrus $\times$ latifolia Tanaka ex Q. Jiménez
}

López-Fortoso F. ${ }^{1}$, González-Arnao M. T. ${ }^{1}$, Bulbarela-Marini J. E. ${ }^{1}$, Pastelín-Solano M. C. ${ }^{1}$, Guevara-Valencia $\mathrm{M} .^{1}{ }^{1}$ Rascón-Díaz, M. P. ${ }^{1}$, Cruz-Cruz C. A. ${ }^{1}$, Castañeda Castro O. ${ }^{{ }^{*}}$

${ }^{1}$ Universidad Veracruzana. Facultad de Ciencias Químicas, Orizaba, Veracruz, México.

*Corresponding author: odcastaneda@uv.mx

\begin{abstract}
Objective: To physically and chemically characterize clonal selections of Persian lime (Citrus $\times$ latifolia Tanaka ex $Q$. Jiménez)

Design/Methodology/Approach: The principal components analysis was employed, using a mixed data factorial analysis model. Genotype distribution was graphed using principal components with the k-medoids method, while a Gower's dissimilarity matrix was determined for the conglomerate analysis and a dendrogram was developed using Ward's minimum variance cluster method. For the morphological characterization of the fruits, the study considered the following trees: Citrus volkameriana, Citrus macrophylla, Citrus paradisi $\times$ Poncirus trifoliata, $\times$ Citroncirus spp., and Citrus $\times$ aurantium. The fruit's diameter, length, weight, color, and shape were analyzed, in addition to its base shape, tip shape, surface texture, albedo adherence, number of seeds, ripening rate, juice weight, juice yield, $\mathrm{pH}$, 'Brix, and titratable acidity. Data were analyzed using R software and the factoextra and FactoMineR packages.
\end{abstract}

Results: The physical and chemical traits of Persian lime fruit vary due to the correlations between the types of rootstock that are cultivated in the citrus zone studied.

Study Limitations/Implications: Farmers do not know which clone or type of plant material they propagate; they simply select clones that show outstanding morpho-agronomical traits.

Findings/Conclusions: The morphological diversity and quality of the fruit is related to the type of rootstock used in its propagation, in addition to internal and external traits in Citrus macrophylla standing out in fruit quality.

Key words: Persian lime, graft, rootstock, shoot, accessions.

\section{INTRODUCTION}

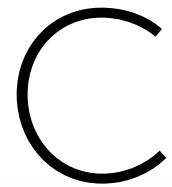

onsumption of Persian lime (Citrus $\times$ latifolia Tanaka ex $Q$. Jiménez) is on the rise globally, due to it being a source of antioxidants favorable for human health, in addition to its multiple uses when consumed fresh or processed (Habermann and Claro, 2014). The traits that make it more attractive to consumers are its less acidic taste, higher juice content, lack of seeds, and a larger fruit size (Hassanzadeh et al., 2017).

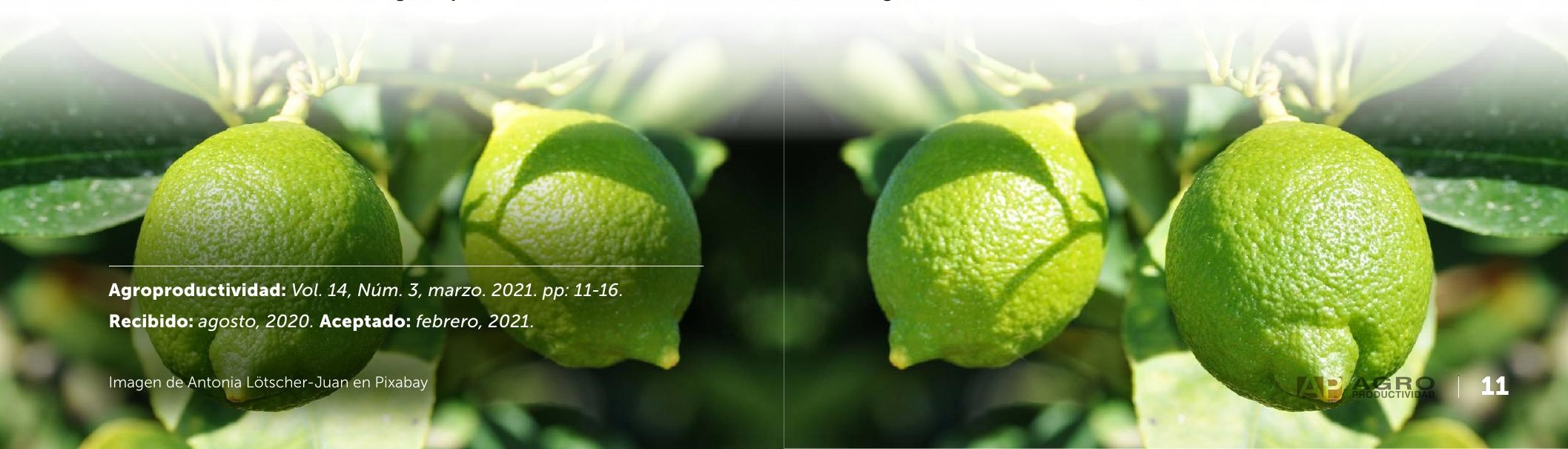


Mexico is among the top producers of citrus fruits in the world (FAOESTAT, 2018) and is the primary producer of Persian lime in the world (Fernandez et al., 2015). According to the Ministry of Agriculture and Rural Development (Secretaría de Agricultura y Desarrollo Rural, SADER, 2018), the state of Veracruz is the top producer of Persian lime in the country. The citrus-producing zone of Cuitláhuac, Veracruz, is considered to be the zone with second-highest Persian lime production, which represents an important economic and social activity thanks to fruit exports destined mainly toward the United States (Caamal-Cauich et al., 2017).

Persian lime is an acidic lime and is the only natural triploid $(3 n=27)$ derived from a cross between Citrus medica as the female parent and Citrus micrantha (Curk et al., 2016). It has non-viable pollen and ovules; therefore, its fruit are parthenocarpic or seedless (Moore, 2001), which is why there are no varieties and they are considered to be selections or clones (Santos et al., 2013).

Rivera-Cabrera et al. (2010) stipulate that they could be "Quebra galho" (a local Brazilian selection contaminated by viroids). In contrast, Curti et al. (2017) affirm that the propagated clone is SRA58, of French origin; however, the National Epidemiology, Quarantine, and Plant Sanitation Station (Estación Nacional de Epidemiología, Cuarentena y Saneamiento Vegetal, ENECUSaV) states that its origin is in the United States. Due to these varying theories, the Persian lime clones farmed in Mexico are believed to be of unknown origin.
The spontaneous mutations and variations that occur in citrus buds or budsticks have created novel phenotypic variations that result in new, superior traits, such as greater yield and fruit quality, resistance to pathogens, and tolerance to abiotic and biotic stress. Subsequently, vegetative propagation can generate a new variety. At this point, a clonal selection is established (Rouiss et al., 2018; Thi-Lam and Ishikawa, 2018). Therefore, morphological characterization allows for defining the accession groups with outstanding agronomic traits and high genetic diversity (Moreno-Ramírez et al., 2019). Thus, the present study had the objective of morphologically characterizing the potential selections of Persian lime that are propagated in the citrusproducing zone of Cuitláhuac, Veracruz.

\section{MATERIALS AND METHODOLOGY}

Ripe Persian lime fruits were collected following the methodology described in the Mexican norm NMX-FF-077-1996, within similar agronomic-management conditions implemented in commercial orchards in the citrus-producing zone of Cuitláhuac, Veracruz, Mexico, which encompasses the municipalities of Cuitláhuac, Tierra Blanca, Tlalixcoyan, and Paso del Macho, located at altitudes between 27 and $345 \mathrm{~m}$.

\section{Morphological Characterization}

The morphological characterization of the fruits was done according to the morphological descriptors implemented by the International Plant Genetic Resources Institute (IPGRI), and these were: Rootstock 1) Citrus volkameriana, 2) Citrus macrophylla, 3) Citrus paradisi $\times$ Poncirus trifoliata, 4) $\times$ Citroncirus spp.), 5) Citrus $\times$ aurantium), fruit diameter and length ( $\mathrm{cm})$, fruit weight ( $\mathrm{g}$ ), fruit color, fruit shape (spheroid, ellipsoidal, pyriform, oblique, obloid, ovoid), fruit base shape (with neck, convex, truncate, concave, pinched concave, pinched with neck), fruit tip shape (breast-shaped, pointy, rounded, truncate, sunken), fruit surface texture (smooth, rough, papillary, pock-marked, uneven, striated), albedo adherence (weak, medium, strong), number of seeds per fruit, ripening rate, juice weight, juice yield, $\mathrm{pH},{ }^{\circ} \mathrm{Brix}$, and titratable acidity. The fruit color determination was based on the citrus fruit color index (Jiménez et al., 1981) using the CR-200 model Konica Minolta ${ }^{\circledR}$ colorimeter. The Brix degrees and juice $\mathrm{pH}$ were determined based on the methodologies described by the OECD (2018). Juice yield was expressed in yield percentage, and Total Soluble Solids ( ${ }^{\circ}$ Brix) were analyzed with a portable refractometer (Model HI 96801, 0 to $85 \%$ Brix). The $\mathrm{pH}$ was measured using potentiometry with an Oakton ${ }^{\circledR}$ potentiometer (model pH 700, USA). Titratable juice acidity was measured using $10 \mathrm{~mL}$ of juice and $50 \mathrm{~mL}$ of distilled water and was titrated with $\mathrm{NaOH}$ $0.1 \mathrm{M}$ until reaching $\mathrm{pH}$ of 8.1 , also measured using potentiometry, and the data were expressed in \% of acidity, which are equivalents for citric acid and ripening rate.

\section{Experiment Design and Statistical Analysis}

The data were analyzed in a single matrix. The principal components analysis (PCA) was done using a factorial analysis of mixed data model (FAMD). Genotype distribution was graphed with the first two principal components (PC) using the k-medoids method (PAM). For the cluster analysis, a Gower's dissimilarity matrix was determined and a dendrogram was made using Ward's 
minimum variance cluster criterion method (Borcard et al., 2018). Data analysis was carried out using R software (version 3.6.1) with the factoextra and FactoMineR packages (Kassambara, 2017).

\section{RESULTS AND DISCUSSION}

Significant differences were found in $58 \%$ of the morphological traits analyzed, indicating that morphological diversity exists in Persian lime, but only eight morphological traits did not present significant effects on morphological diversity, indicating that the most important and statistically significant correlations are related to the categorical traits.

The correlation of the PCA identified 11 highly discriminatory traits that explain $69.73 \%$ of the variation of five principal components (Table 1). The continuous traits of highest variability were fruit length, fruit diameter and weight, juice weight, ${ }^{\circ}$ Brix, and ripening rate, while the categorical traits that showed the most variability were rootstock, fruit shape, fruit base and fruit tip shape, and texture.

Based on the distribution of the genotypes along the plane determined by PC1 and PC2, three groups were defined in terms of spatial distribution for the first two PC.

Group one is made up of fruits that show the highest ripening rate, ${ }^{\circ}$ Brix and color, spheroid shape, rough texture, and a concave, pinched fruit base shape and pointy fruit tip shape. In general, the fruits were smaller in size, and the rootstock Citrus $\times$ aurantium, also known locally as sour orange, is present in $100 \%$ of the genotypes that make up this group.

Group two was made up of fruits with intermediate values in the quantitative traits for citric acid percentage, length, diameter, and fruit and juice weight. However, the fruit's qualitative traits presented an ellipsoidal and spheroid shape, papillary and rough texture, breastshaped base, convex, and pinchedconcave fruit base shape. In addition, this group was $75 \%$ made up of Citrus volkameriana (volkamer lemon), 12\% of Citrus paradisi $\times$ Poncirus trifoliata
(C35 citrange), and 13\% of Citroncirus spp. (swingle citrumelo) rootstocks.

Group three was made up of fruit genotypes with higher weight, diameter, length, juice weight, and citric acid percentage. With respect to the qualitative traits of the fruit, these showed truncated and convex base shapes, obloid and ellipsoid shapes, and rough and papillary texture. In the end, $100 \%$ of the genotypes conforming this group were grafted with rootstock from the alemow lemon or Citrus macrophylla (Figure 1).

The morphological variability of the Persian lime exhibits diverse quantitative and qualitative morphological traits, although this variability in morphological traits is correlated with the rootstock used. These results coincide with those reported by Stenzel and Neves (2004), who evaluated the IAC-5 clone of Persian lime that was grafted on different rootstocks, and showed that the fruit presents diversity in quality and characteristics depending on the type of rootstock utilized.

In the dendrogram shown in Figure 2, five groups are formed according to Ward's method, and these groups showed a similar relationship with the groups formed in the principal components analysis, which is why the association shown by the groups is determined by the type of rootstock and by characteristics in fruit size. Group I was observed to consist of fruits with

\begin{tabular}{|c|c|c|c|c|c|}
\hline \multirow{2}{*}{ Character } & \multicolumn{5}{|c|}{ Eigenvalues } \\
\hline & CP1 & $\mathrm{CP} 2$ & CP3 & CP4 & CP5 \\
\hline Fruit diameter (cm) & 0.62 & 0.03 & 0.032 & 0.058 & 0.000 \\
\hline Fruit length $(\mathrm{cm})$ & 0.63 & 0.02 & 0.047 & 0.082 & 0.041 \\
\hline Fruit weight (g) & 0.72 & 0.02 & 0.015 & 0.054 & 0.022 \\
\hline Juice weight (g) & 0.56 & 0.13 & 0.007 & 0.129 & 0.008 \\
\hline Brix grade & 0.005 & 0.34 & 0.154 & 0.040 & 0.019 \\
\hline Maturity index & 0.09 & 0.35 & 0.118 & 0.184 & 0.022 \\
\hline Rootstock & 0.79 & 0.73 & 0.300 & 0.520 & 0.760 \\
\hline Fruit shape & 0.55 & 0.44 & 0.186 & 0.265 & 0.085 \\
\hline Fruit base shape & 0.79 & 0.01 & 0.603 & 0.231 & 0.144 \\
\hline Fruit apex shape & 0.05 & 0.72 & 0.001 & 0.120 & 0.001 \\
\hline Fruit texture & 0.20 & 0.23 & 0.243 & 0.060 & 0.009 \\
\hline Eigenvalues & 5.62 & 3.45 & 2.67 & 2.17 & 1.37 \\
\hline Variation explained (\%) & 25.55 & 15.68 & 12.14 & 9.88 & 6.27 \\
\hline Accumulated variation (\%) & 25.55 & 41.24 & 53.38 & 63.26 & 69.53 \\
\hline
\end{tabular}

CP: principal component. 


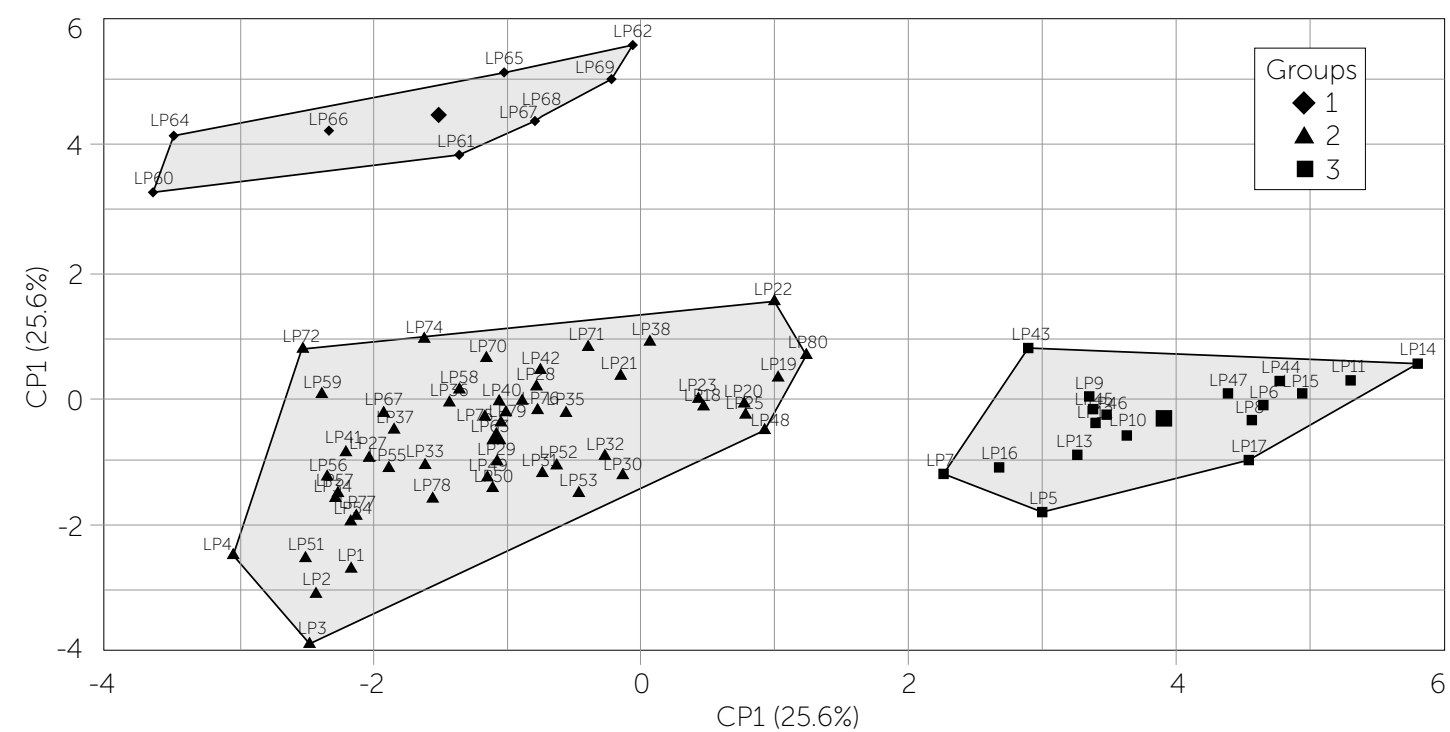

Figure 1. Dispersion of 80 Persian lemon genotypes, based on the first two main components of the analysis of 11 morphological characters.

the greatest diameter, length, and juice weight, as well as a truncated obloid and ellipsoid shape, rough texture, and with rootstock from Citrus macrophylla. In addition, the group showed a similarity distance of 0.4, while groups II and III consisted of fruits showing similar characteristics, only differing in the base shape. Group IV was made up of fruits with the smallest size, but they showed an intense green color and higher amount of ${ }^{\circ}$ Brix, with Citrus $x$ aurantium rootstock. Finally, group $V$ presented genotypes that were grafted with Citrus paradisi $\times$ Poncirus trifoliata and Citroncirus spp.

García-López et al. (2017) determined that the parameters that ensure quality in the Persian lime fruit with respect to $\mathrm{pH}$ should be between 2.0 and 2.3, and values between 7.4 and $7.7^{\circ}$ Brix; thus, these results coincide with those reported by Zandkarimi et al. (2011), who mention that in limes and lemons, the most important morphological traits are fruit weight and length, in addition to their physicochemical characteristics. Authors like Grüneberg et al. (2009)

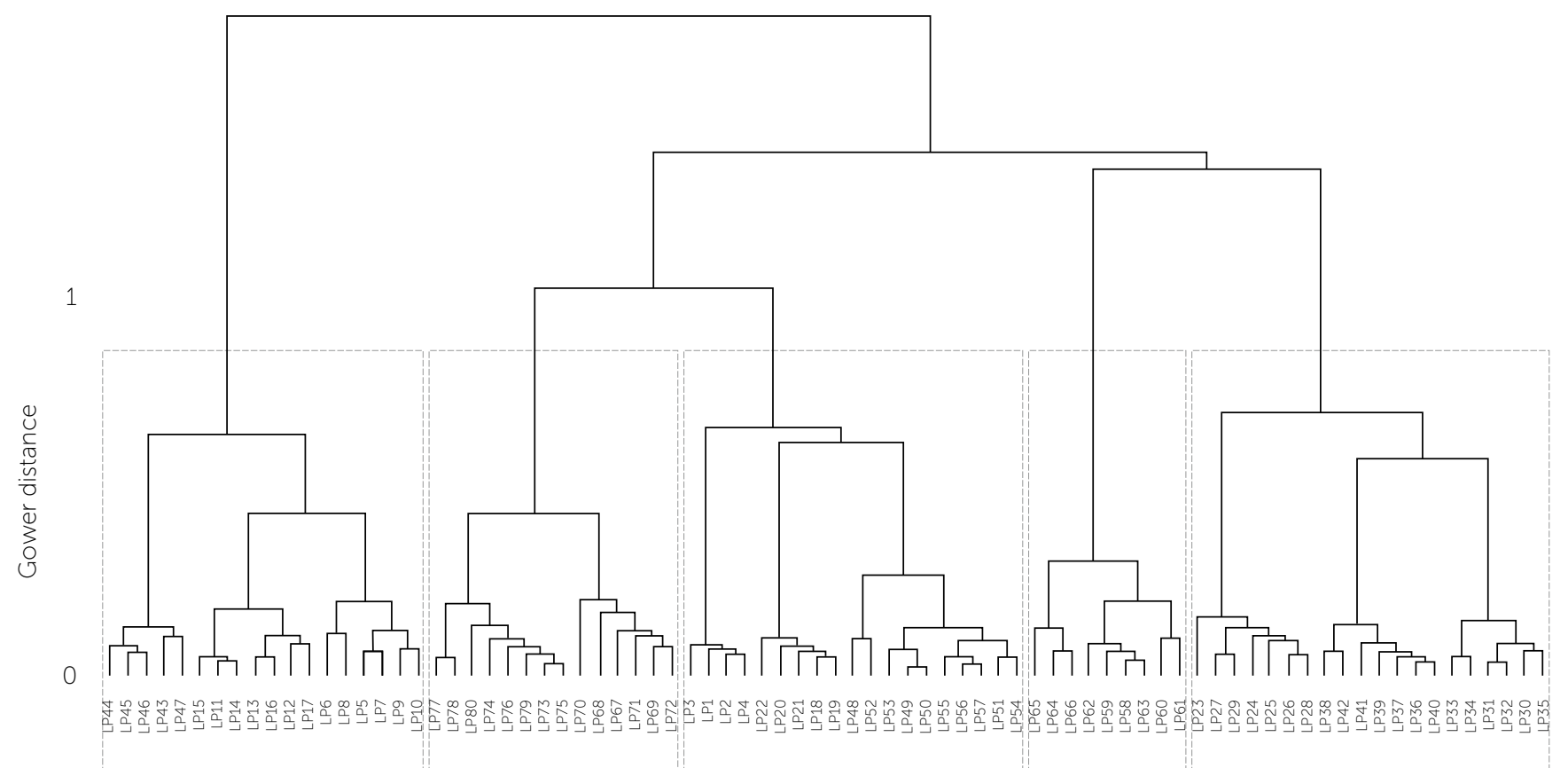

Figure 2. Dendrogram obtained by Ward's method of 80 Persian lemon genotypes based on 19 morphological characters. 
indicate that in clonal crops, yield is determined by epistasis effects that cause a rise in morphological variation. Likewise, Medina-Urrutia et al. (2009) link the behavior of rootstocks to different types of soil on which adaptability to the environment depends, resulting in homogeneous production; in turn, Espinoza-Núñez et al. (2011) indicate that the alemow lemon presents high yields under irrigation conditions, while Khankahdani et al. (2019) indicate that C. volkameriana functions as rootstock in Persian lime from the first stages of grafting by producing vigorous plants with vegetative growth and greater absorption of iron, copper, zinc, and manganese. This relationship is of great importance due to the graft-rootstock interaction, which determines the optimal growth of the graft. Tietel et al. (2020) found that the rootstock affects yield and biochemical quality in mandarins (sugar and acidity), such that $C$. volkameriana did not increase the total sugar index, however, sour orange did increase the sugar content.

\section{CONCLUSIONS}

The morphological diversity and fruit quality of Persian lime is related to the type of rootstock used for its propagation. Based on the morphological traits evaluated, Citrus macrophylla provides the best physical and chemical characteristics of lime fruits.

\section{AKNOWLEDGEMENTS}

The authors thank the National Science and Technology Council (Consejo Nacional de Ciencia y Tecnología, CONACYT) for the scholarship supporting the Master's in Sicence program on Biological Processes at Universidad Veracruzana.

\section{REFERENCES}

Berdeja-Arbeu, R., Aguilar-Méndez, L., Moreno-Velázquez, D., VázquezHuerta, G., Ontiveros-Capurata, R., \& Ibañez-Martínez, X. (2016). Calidad de fruta de lima Persa en diferentes portainjertos en Veracruz, México. Acta Agrícola y Pecuaria 2(1): 17-22

Borcard, D., Gillet, F., \& Legendre, P. (2018). Numerical ecology with R Second edition. Springer. https://doi.org/10.1007/978-3-31971404-2

Caamal-Cauich, I., Pat-Fernández, V., Jerónimo-Ascencio, F., SantoyoRodríguez, l., \& Ramos-García, J. (2014). Análisis de los costos de la producción de limón Persa en el municipio de Tlapacoyan, Veracruz. Revista Científica Biológico Agropecuaria 2(3): 192200

Curti-Díaz, S. A., Hernández-Guerra, C., Sandoval-rincón, A. J., \& Loredo-Salazar, X, R. (2017). Caracterización agronómica de cinco clones de limón Persa (Citrus latifolia) injertados en limón Volkameriana (Citrus volkameriana). Reunión Científica-Tecnológica, Forestal y Agropecuaria, Veracruz 1(1) 2393-2400
Curk, F., Ollitrault, F., Garcia-Lor, A., Luro, F., Navarro, L., \& Ollitrault, P. (2016). Phylogenetic origin of limes and lemons revealed by cytoplasmic and nuclear markers. Annals of botany 117(4), 565583.

Espinoza-Núñez, E., Mourão-Filho, F. D. A. A., Stuchi, E. S., CantuariasAvilés, T., \& dos Santos Dias, C. T. (2011). Performance of 'Tahiti' lime on twelve rootstocks under irrigated and non-irrigated conditions. Scientia horticulturae, 129(2), 227-231.

FAO (2018) http://www.fao.org/faostat/en/\#data/QC

FAMD, MFA, HCPC, factoextra. STHDA, Francia, 1st edition.

Fernandez, L. G., Aguilar L. A., Azzaro-Pantel, C., Miranda-Ackerman, M. A., Purroy, V. R., \& Pérez S. M. R. (2015). Behavior patterns related to the agricultural practices in the production of Persian lime (Citrus latifolia Tanaka) in the seasonal orchard. Computers and Electronics in Agriculture, 116: 162-172.

Habermann, G. \& Claro, M. (2014). History, ecology and challenges of citrus production in tropical and subtropical areas. In K (Ed.). Haya, Citrus molecular phylogeny, antioxidant properties and medicinal uses 1-9 pp. New York, EUA: Nova P.

Hassanzadeh, H., Rastegar, S., Golein, B., Golmohammadi, M., \& Aboutalebi, A. (2017). Genetic diversity in Persian lime (Citrus latifolia Tanaka) accessions using morphological and molecular markers. Agriculture \& Forestry. 63. 221-231 pp.

García, F., Herrera, J., Pérez, J., Alatriste, I., \& Contreras, A. (2017). Relation Between Color and Physical-Chemical Parameters of Persian lime (Citrus latifolia) from central Veracruz, Mexico. Agroproductividad, 10(9), 9-14.

Jimenez, C.M., Cuquerella, J., \& Martinez-Javaga, J. M. (1981). Determination of Citrus color Index for Citrus degreening. Proceedings of the International Society of Citriculture, 2:750753.

Kassambara, A. (2017). Practical guide to principal component Methods in R: PCA, M (CA)

Khankahdani, H. H., Rastegar, S., Golein, B., Golmohammadi, M., \& Jahromi, A. A. (2019). Effect of rootstock on vegetative growth and mineral elements in scion of different Persian lime (Citrus latifolia Tanaka) genotypes. Scientia horticulturae, 246, 136145

Killini, N., Valim, M. F., Jones, S. E., \& Hijaz, F. (2018). Effect of different rootstocks on the leaf metabolite profile of Sugar Belle mandarin hybrid. Plant Signaling \& Behavior, DOI: https://doi. org/10.1080/15592324.2018.1445934

Kumar, S., Awasthi, O. P., Dubey, A. K., Pandely, R., Sharma, V. K., \& Sharma, R. M. (2017). Root morphology and the effect of rootstocks on leaf nutrient acquisition of $\mathrm{K}$ in now mandarin (Citrus nobilis Loureiro $\times$ Citrus reticulata Blanco). The journal of horticulture science and biotechnology. https://doi.org/10.1 080/14620316.2017.1345333

Lam, D. T., \& Ishikawa, R. (2019). Molecular discrimination of landraces of Citrus species in the Okinawa, Japan. Genetic Resources and Crop Evolution, 66(2), 321-333

Medina-Urrutia, V. M., Robles-González, M. M., \& VelázquezMonreal, J. J. (2009). Comportamiento de dos cultivares de limón mexicano [Citrus aurantifolia (Christm) Swingle] en portainjertos desarrollados en suelos con dos profundidades. Revista Chapingo. Serie horticultura, 15(1) 49-55

Moore, G.A. (2001). Oranges and lemons: clues to the taxonomy of Citrus from molecular markers. TRENDS in Genetics, 17(9) 536-540. 
Moreno-Ramírez, del R. Y., Santacruz-Varela, A., López, P. A., López-Sánchez, H., Córdova-Téllez, L., González-Hernández, V. A., \& López-Ortega, R. (2019). Morphological diversity of Zacatecas Guajillo chile landraces is broad and is given mainly by fruit traits. Emirates Journal of Food and Agriculture, 440-448.

Mumtaz, M., AL-yahyai, R., \& Al-Said, F. (2017). The Lime botany, production and uses. CABI, UK.12(22) 37-42.

NMX-FF-077-1996. Productos alimenticios no industrializados para consumo humano, fruta fresca limón Persa (Citrus latifotia L.) Especificaciones normas mexicanas, dirección general de normas.

OECD. (2018). Guidelines on objective tests to determine quality of fruit and vegetables, dry and dried produce. OECD fruit and vegetables scheme.

Rivera-Cabrera, F., Ponce M., Díaz de León F., Villegas A., \& Pérez Laura. (2010). Acid Limes. A Review. Fresh Produce, 4, pp 116-112.

SADER (2017) www.gob.mx/siap/acciones-y-programas/produccion-agricola-33119

Shu-wei, Z., Gui-Xiang, H., Xin-Hua, H., Jie-Chun, P., \& Feng, D. (2015). Atudy on genetic diversity of lemon, lime, and rangpur germplasm resources with SCOT and ISSR markers. Acta Hort, 1065: 97-104.

Stenzel, N. M. C., \& Neves, C. S. V. J. (2004). Porta-enxertos para a limeira ácida Tahiti. Scientia Agricola, 61(2), 151-155.

Talon, M., \& Gmitter, F. G. (2008). Citrus genomics. International Journal of Plant Genomics. DOI: $10.1155 / 2008 / 528361$.

Tietel, Z., Srivastava, S., Fait, A., Tel-Zur, N., Carmi, N., \& Raveh, E. (2020). Impact of scion/ rootstock reciprocal effects on metabolomics of fruit juice and phloem sap in grafted Citrus reticulata. PloS one, 15(1).

Uzun, A., Gulsen, O., Kafa, G., \& Seday, U. (2008). Field performance and molecular.

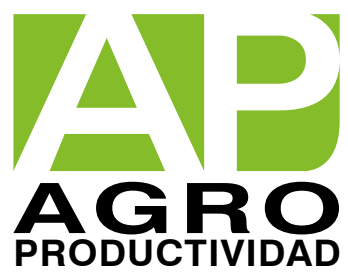

